\title{
Mesenchymal stem cells in transplantation and tissue regeneration
}

\author{
Martin J. Hoogduijn ${ }^{*}$ and Frank J. M. F. Dor ${ }^{2}$ \\ 1 Transplantation Laboratory, Department of Internal Medicine, Erasmus MC, University Medical Center, Rotterdam, Netherlands \\ 2 Division of Transplant Surgery, Department of Surgery, Erasmus MC, University Medical Center, Rotterdam, Netherlands \\ *Correspondence: m.hoogduijn@erasmusmc.nl
}

Mesenchymal stem cells (MSC) were identified in the 1960s as bone marrow cells capable of osteogenic differentiation (Friedenstein and Petrakova, 1966). In the following decennia, these cells were further attributed with the capacity to differentiate into adipogenic, chondrogenic, and myogenic lineages (Pittenger et al., 1999), to secrete trophic factors that stimulate other cell types (Caplan and Dennis, 2006), and to possess immunomodulatory properties (Di Nicola et al., 2002). Cells with these properties were found not to be restricted to the bone marrow, but also to reside at other locations including adipose tissue (Zuk et al., 2002), skin (Toma et al., 2001), and in organs like liver, kidney, and brain (da Silva Meirelles et al., 2006). In particular adipose tissue has proven to be a valuable source of MSC due to its accessibility and its abundance.

The characteristics of MSC initiated interest in their potential clinical use for tissue regenerative and immunomodulatory purposes. The first clinical applications were in the treatment of osteogenesis imperfecta (Horwitz et al., 1999) and graft versus host disease (Le Blanc et al., 2004). Since then, the use of MSC for the treatment of a variety of diseases has been investigated in clinical trials, including in Crohn's disease (Duijvestein et al., 2010), myocardial infarction (Hare et al., 2009), rheumatoid arthritis (Liang et al., 2011), multiple sclerosis (Freedman et al., 2010), and organ transplantation (Dahlke et al., 2009).

In organ transplantation, the use of MSC is aimed at the prolongation of allograft survival. Thus, MSC therapy may be used for the treatment of acute rejection, but also to prevent currently untreatable chronic rejection. Furthermore, there is evidence that MSC therapy has a tissue regenerative component that repairs organ injury caused by immunological or ischemic events and thereby prevents the loss of organ trans- plants in animal models (Morigi et al., 2008; Popp et al., 2008). This may offer another window of opportunity for MSC therapy in particular shortly after transplantation, when organ loss peaks partly due to ischemia-reperfusion injury of the graft.

As with all therapies in development, the reasons for the use of MSC as an immunomodulatory and regenerative agent should be taken into careful consideration. Open questions are whether MSC therapy is effective and, if so, whether it is more efficient than existing drugs? Are there safety issues involved? Is MSC therapy cost-effective? Whether MSC can replace existing drugs is not clear at the moment as the efficacy of MSC therapy is difficult to determine. A one to one comparison of efficacy between MSC and conventional drugs is not easy to make. While pharmacological drugs target specific molecular pathways, MSC have a wide range of effects. Furthermore, while pharmaceuticals can be given to patients at a daily frequency, for safety, practical, and financial reasons there is a limit to the frequency at which cell therapy can be applied. However, at these early stages, a head on comparison with standard therapy may not be required as the use of MSC will primarily be aimed at applications where conventional therapies fail. As such, MSC will be applied as an adjuvant for current therapies. In the more distant future, MSC may be used to replace medication that has significant side effects, as may be the case with calcineurin inhibitors in organ transplantation. Although very effective in preventing organ rejection, calcineurin inhibitors are nephrotoxic, thereby limiting the life span of kidney transplants. Side effects of MSC therapy have not been reported yet, but certainly some will occur when MSC are used more widely. A high incidence of infections after MSC therapy in graft versus host disease patients was recently reported (von Bahr et al., 2011). Whether the risk for infection was significantly elevated in MSC treated patients compared to controls was however not demonstrated. To be able to map the side effects of MSC therapy, these effects should be investigated parallel to their clinical effects in placebo-controlled studies. Nevertheless, from where we stand today, we can conclude with considerable certainty that the infusion of MSC does not harbor serious health threats.

While the in vitro properties of MSC suggest a beneficial effect of MSC in immunological and degenerative diseases and early clinical trials are triumphant about the feasibility and safety of MSC therapy, there is thus far little evidence that MSC are effective in curing disease. The effectiveness of MSC therapy needs to be established in follow up trials and knowledge of the mechanisms of action of MSC may help optimizing the therapy. The mechanisms of action of MSC after infusion may be very different to those observed in vitro. There is for instance accumulating evidence that MSC are short-lived after infusion (Popp et al., 2008). Even though, long-term effects are observed after infusion of MSC. These effects may be mediated by other cell types to which the effect of MSC is transferred. It has been demonstrated that MSC induce immunoregulatory capacity of $\mathrm{T}$ cells (Prevosto et al., 2007) and macrophages (Maggini et al., 2010). More knowledge on how MSC interact with these cell types could provide tools for optimizing MSC therapy.

An alternative approach for MSC therapy is to design drugs or therapies that target tissue resident MSC. MSC respond to cytokines and growth factors by changing their immunoregulatory function and/or their differentiation status. Therefore, these factors could be the basis of such drugs, which should induce a specific response in MSC that reside in transplanted organs. In 
this way, MSC therapy can be more localized and more specific compared to the infusion of MSC.

In order for a therapy to be successful, it needs to be cost-effective. MSC treatment is a costly therapy as MSC need to be cultured under GMP conditions. In particular the generation of custom-made, i.e., autologous, MSC of clinical grade is an expensive process. Centralization of MSC production at specialized laboratories can reduce costs. Furthermore, for some applications allogeneic MSC may be suitable and these can be generated in large batches, which further brings down costs. A real cost-effect analysis can however only be made once the efficacy of MSC therapy has become clear.

Summarizing, MSC have the potential to be used as an immunomodulatory and regenerative therapy in organ transplantation and immune and degenerative diseases. Basic and clinical research will have to point toward the right directions on the effective use of MSC. In this special feature of Frontiers in Immunology, the most recent findings on the immunomodulatory capacity of MSC, such as their interaction with regulatory $\mathrm{T}$ cells, and on their potential to induce regeneration of liver, kidney, and heart after ischemia-reperfusion injury and of bone and cartilage damage in rheumatoid and osteoarthritis, will be presented. Furthermore, challenges on how to generate a high quality and effective cell product will receive attention. Finally, the use of MSC in transplantation and regenerative medicine and ideas on how to drive this field forward will be reviewed and discussed by leaders in the field. We are confident that this special topic will generate new directions to be followed in translational research and clinical trials.

\section{REFERENCES}

Caplan, A. I., and Dennis, J. E. (2006). Mesenchymal stem cells as trophic mediators. J. Cell. Biochem. 98, 1076-1084.

da Silva Meirelles, L., Chagastelles, P. C., and Nardi, N. B. (2006). Mesenchymal stem cells reside in virtu- ally all post-natal organs and tissues. J. Cell. Sci. 119, 2204-2213.

Dahlke, M. H., Hoogduijn, M., Eggenhofer, E., Popp, F. C., Renner, P., Slowik, P., Rosenauer, A., Piso, P., Geissler, E. K., Lange, C., Chabannes, D., Mazzanti, B., Bigenzahn, S., Bertolino, P., Kunter, U., Introna, M., Rambaldi, A., Capelli, C., Perico, N., Casiraghi, F., Noris, M., Gotti, E., Seifert, M., Saccardi, R., Verspaget, H.W., van Hoek, B., Bartholomew, A., Wekerle, T., Volk, H. D., Remuzzi, G., Deans, R., Lazarus, H., Schlitt, H. J., Baan, C. C., and Group, M. S. (2009). Toward MSC in solid organ transplantation: 2008 position paper of the MISOT study group. Transplantation 88, 614-619.

Di Nicola, M., Carlo-Stella, C., Magni, M., Milanesi, M., Longoni, P. D., Matteucci, P., Grisanti, S., and Gianni, A. M. (2002). Human bone marrow stromal cells suppress T-lymphocyte proliferation induced by cellular or nonspecific mitogenic stimuli. Blood 99, 3838-3843.

Duijvestein, M., Vos, A. C., Roelofs, H., Wildenberg, M.E., Wendrich, B. B., Verspaget, H.W., Kooy-Winkelaar, E. M., Koning, F., Zwaginga, J. J., Fidder, H. H., Verhaar, A. P., Fibbe, W. E., van den Brink, G. R., and Hommes, D. W. (2010). Autologous bone marrow-derived mesenchymal stromal cell treatment for refractory luminal Crohn's disease: results of a phase I study. Gut 59, 1662-1669.

Freedman, M. S., Bar-Or, A., Atkins, H. L., Karussis, D., Frassoni, F., Lazarus, H., Scolding, N., Slavin, S., Le Blanc, K., Uccelli, A., and Group, M. S. (2010). The therapeutic potential of mesenchymal stem cell transplantation as a treatment for multiple sclerosis: consensus report of the International MSCT Study Group. Mult. Scler. 16, 503-510.

Friedenstein, A. J., Piatetzky, S. II, and Petrakova, K. V. (1966). Osteogenesis in transplants of bone marrow cells. J. Embryol. Exp. Morphol. 16, 381-390.

Hare, J. M., Traverse, J. H., Henry, T. D., Dib, N., Strumpf, R. K., Schulman, S. P., Gerstenblith, G., DeMaria, A. N., Denktas, A. E., Gammon, R. S., Hermiller, J. B. Jr., Reisman, M.A., Schaer, G. L., and Sherman, W. (2009). A randomized, double-blind, placebo-controlled, dose-escalation study of intravenous adult human mesenchymal stem cells (prochymal) after acute myocardial infarction. J. Am. Coll. Cardiol. 54, 2277-2286.

Horwitz, E. M., Prockop, D. J., Fitzpatrick, L. A., Koo, W. W., Gordon, P. L., Neel, M., Sussman, M., Orchard, P., Marx, J. C., Pyeritz, R. E., and Brenner, M. K. (1999). Transplantability and therapeutic effects of bone marrow-derived mesenchymal cells in children with osteogenesis imperfecta. Nat. Med. 5, 309-313.

Le Blanc, K., Rasmusson, I., Sundberg, B., Gotherstrom, C., Hassan, M., Uzunel, M., and Ringden, O. (2004). Treatment of severe acute graft-versus-host disease with third party haploidentical mesenchymal stem cells. Lancet 363, 1439-1441.

Liang, J., Li, X., Zhang, H., Wang, D., Feng, X., Wang, H., Hua, B., Liu, B., and Sun, L. (2011). Allogeneic mesenchymal stem cells transplantation in patients with refractory RA. Clin. Rheumatol. doi: 10.1007/ s10067-011-1816-0

Maggini,J., Mirkin, G., Bognanni, I., Holmberg,J., Piazzon, I. M., Nepomnaschy, I., Costa, H., Canones, C., Raiden, S., Vermeulen, M., and Geffner, J. R. (2010). Mouse bone marrow-derived mesenchymal stromal cells turn activated macrophages into a regulatory-like profile. PLoS ONE5, e9252.doi: 10.1371/journal.pone.0009252 Morigi, M., Introna, M., Imberti, B., Corna, D., Abbate, M., Rota, C., Rottoli, D., Benigni, A., Perico, N., Zoja, C., Rambaldi,A., Remuzzi, A., and Remuzzi, G. (2008). Human bone marrow mesenchymal stem cells accelerate recovery of acute renal injury and prolong survival in mice. Stem Cells 26 2075-2082.

Pittenger, M. F., Mackay, A. M., Beck, S. C., Jaiswal, R. K., Douglas, R., Mosca, J. D., Moorman, M. A., Simonetti, D.W., Craig, S., and Marshak, D. R. (1999). Multilineage potential of adult human mesenchymal stem cells. Science 284, 143-147.

Popp, F. C., Eggenhofer, E., Renner, P., Slowik, P., Lang, S. A., Kaspar,H., Geissler,E.K.,Piso,P.,Schlitt,H.J., and Dahlke, M. H. (2008). Mesenchymal stem cells can induce longterm acceptance of solid organ allografts in synergy with low-dose mycophenolate. Transpl. Immunol. 20, 55-60.

Prevosto, C., Zancolli, M., Canevali, P., Zocchi, M. R., and Poggi, A. (2007). Generation of CD4+ or CD8+ regulatory $\mathrm{T}$ cells upon mesenchymal stem celllymphocyte interaction. Haematologica 92, 881-888.

Toma,J.G., Akhavan, M., Fernandes, K. J., Barnabe-Heider, F., Sadikot, A., Kaplan, D. R., and Miller, F. D. (2001). Isolation of multipotent adult stem cells from the dermis of mammalian skin. Nat. Cell Biol. 3778-784. von Bahr, L., Sundberg, B., Lonnies, L., Sander, B., Karbach, H., Hagglund, H., Ljungman, P., Gustafsson, B., Karlsson, H., Le Blanc, K., and Ringden, O. (2011). Long-term complications, immunologic effects, and role of passage for outcome in mesenchymal stromal cell therapy. Biol. Blood Marrow Transplant. doi: 10.1016/j.bbmt.2011.07.023

Zuk,P.A.,Zhu,M., Ashjian, P., De Ugarte, D.A., Huang, J. I., Mizuno, H., Alfonso,Z.C., Fraser,J.K., Benhaim, P., and Hedrick,M.H. (2002). Human adipose tissue is a source of multipotent stem cells. Mol. Biol. Cell 13, 4279-4295.

Received: 29 November 2011; accepted: 12 December 2011; published online: 28 December 2011.

Citation:Hoogduijn MJandDorFJMF (2011)Mesenchymal stem cells in transplantation and tissue regeneration. Front. Immun. 2:84. doi: 10.3389/fimmu.2011.00084

This article was submitted to Frontiers in Alloimmunity and Transplantation, a specialty of Frontiers in Immunology. Copyright $\odot 2011$ Hoogduijn and Dor. This is an openaccess article distributed under the terms of the Creative Commons Attribution Non Commercial License, which permits non-commercial use, distribution, and reproduction in other forums, provided the original authors and source are credited. 